\title{
POTENT UREASE INHIBITORS: DESIGN, SYNTHESIS, MOLECULAR DOCKING AND IN-SILICO ADME EVALUATION OF DIHYDROPYRIMIDINE PHTHALIMIDE HYBRIDS
}

\author{
Ahmed A. E. Mourad ${ }^{1, *}$, Mai A. E. Mourad ${ }^{2}$ \\ ${ }^{1}$ Department of Pharmacology and Toxicology, Faculty of Pharmacy, Port-Said \\ University, Port-Said, Egypt. \\ ${ }^{2}$ Department of Medicinal Chemistry, Faculty of Pharmacy, Port-Said University, Port- \\ Said, Egypt.
}

*Corresponding author: Email: ahmed.mourad@yahoo.com

\begin{abstract}
Urease inhibition has gained much attention for management of several gastrointestinal and kidney related diseases including peptic ulcer, urolithiasis as well as pyelonephritis. In the current study, novel dihydropyrimidine phthalimide hybrids were synthesized and evaluated for their in vitro urease inhibitory activity. The synthesized hybrids were tested their cytotoxic activity. Additionally, the pharmacokinetic properties and drug-likeness were calculated for all synthesized hybrids. Among the synthesized hybrids, compounds $10 \mathrm{~g}, 10 \mathbf{e}, 10 \mathrm{~h}, 1 \mathbf{1 0}$, and $10 \mathbf{j}$ achieved greater urease inhibitory activity with $\mathrm{IC}_{50}$ range of $12.6 \pm 0.1$ to $20.1 \pm 1.3 \mu \mathrm{M}$, compared to the standard urease inhibitor, thiourea with $\mathrm{IC}_{50}$ of $21.0 \pm 0.1 \mu \mathrm{M}$. Consistent with our findings, the molecular docking study revealed that the most active compounds are docked well with the active sites of urease enzyme. The structure activity relationship concluded that electronic nature, lipophilicity and steric factor of the substituents markedly influenced the urease inhibitory activity. The pharmacokinetic study showed that our compounds have high oral bioavailability, poor blood brain barrier and CNS permeability as well as they have no teratogenic potential. Finally, the synthesized hybrids are considered safe as indicated by the in vitro cytotoxicity assay.
\end{abstract}

Keywords : Urease inhibitors, Dihydropyrimidine, Phthalimide, Cytotoxicity, Peptic ulcer, Pyelonephritis, Helicobacter pylori. 


\section{Introduction}

Urease hydrolyses urea into ammonia and carbamate. At the physiological $\mathrm{pH}$, carbamate in turn spontaneously breaks down into another molecule of ammonia and carbonic acid (Li et al., 2008). Ureases are biosynthesized by a variety of organisms, including plants, fungi and bacteria; and also exist in nature (Collinand and Orazio, 1993; Krajewska and Ureases, 2009). Although urease is the first enzyme to be isolated and crystallized, its behavior inside the body is not fully discovered (Weber et al., 2008). Urease is greatly implicated in pathogenesis of several gastrointestinal diseases including gastric and peptic ulcers (Hameed et al., 2010; Taha et al., 2015). In the same context, Helicobacter pylori is considered as a major causative agent of peptic ulcers (Hooi et al., 2017). Meanwhile, overexpression of urease enzyme leads to interminable formation of ammonia which boosts the ability of $H$. pylori to encounter the acidic environment of the stomach resulting in gastric inflammation, damaging of gastric mucosa permeability (Stingl et al., 2002). Furthermore, this continuous release of ammonia ultimately increased the risk of developing duodenal and peptic ulcers, gastric adenocarcinoma and gastric lymphoma which may eventually cause cancer of the gastric mucosa (Jr and Blaser, 2002).

Moreover, urease is one of the crucial agents that mediate pyelonephritis, urolithiasis, catheter incrustation and hepatic encephalopathy (Mulvaney and Bremner, 1981, Bayerdörffer and Ottenjann, 1988; Mobley et al., 1995). Fortunately, the family of ureases shares common structural moieties, thus targeting one isozyme will affect the other members of ureases (Macomber et al., 2015).

Therefore, the discovery of effective and secure urease inhibitors is emerged as an important target. In the same context, dihydropyrimidinones are known to possess a wide range of biological activities including urease inhibition (Khan et al., 2016; Muhammad et al., 2017; Iftikhar et al., 2017; Shamim et al., 2018), DPP-4 inhibiton (Mourad et al., 2021), anti-inflammatory (Gong et al., 2015), antihypertensive (Putatunda et al., 2014), anticancer (Hameed et al. 2013) and antimicrobial effects (Rego et al., 2018). Moreover, 3,4-dihydropyrimidin-2(1H)-ones and 4,6dihydroxypyrimidinediones were reported as potent urease inhibitors (Muhammad et al., 2017; Shamim et al., 2018) Additionally, benzylidene indane-1,3-diones and its derivatives have been reported for their potential urease inhibitory activity (Bano et al., 2018) (Figure 1). 
<smiles>[R]c1ccc(C=C2C(=O)NC(=S)NC2=O)cc1</smiles><smiles>[R]c1ccc(NC=C2C(=O)NC(=S)NC2=O)cc1</smiles><smiles>[R6]C(=O)C1=C(C)NC(=S)NC1[Al]</smiles><smiles>[R]C=CC</smiles><smiles>O=C1C(=Cc2cccnc2)C(=O)c2ccccc21</smiles>

Figure 1. Reported dihydropyrimidinediones and benzylidene indane-1,3-diones based urease inhibitors.

So, in the view of the therapeutic importance of urease inhibition, we herein, aimed at utilizing drug design strategy to develop novel entities from gathering dihydropyrimidine and phthalimide moieties; and evaluating their urease inhibitory activity and their safety profile (Figure 2, Scheme 1). Furthermore, the molecular docking study of the synthesized hybrids was performed to get insight into the binding pattern within the protein active site; as well as the pharmacokinetic parameters and the drug-likeness of the synthesized hybrids were further evaluated.

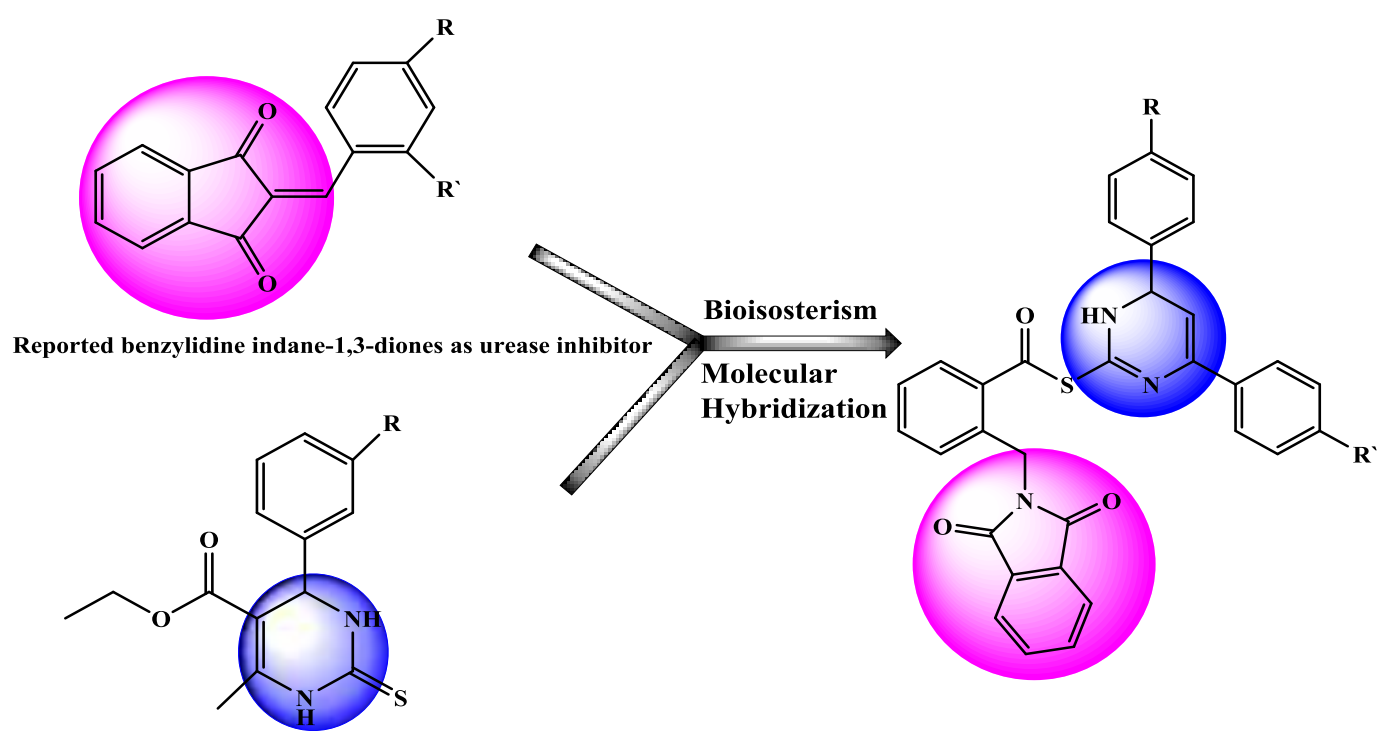

Reported dihydropyrimidine as urease inhibitor 
Figure 2. Diagram represents design of novel urease inhibitors

\section{Materials and methods}

\subsection{Urease inhibition assay}

In 96 well plates, $25 \mu 1$ of Jack bean (Canavalia ensiformis) urease, $55 \mu 1$ of 100 $\mathrm{mM}$ urea and various concentrations of synthesized compounds were incubated for 15 $\min$ at $30^{\circ} \mathrm{C}$. Different concentrations of both synthesized hybrids and substrate were used. Phenol reagent $(0.005 \% \mathrm{w} / \mathrm{v}$ of sodium nitroprusside with $1 \% \mathrm{w} / \mathrm{v}$ phenol $)$ and alkali reagent $(0.5 \%$ of $\mathrm{w} / \mathrm{v} \mathrm{NaOH}$ with $0.1 \%$ of w/v NaOCl$)$ were added to each well. Indophenols method was adopted to evaluate the urease activity based on production of ammonia as previously described (Weatherburn, 1967). Fifty min later, the alteration in absorbance at $630 \mathrm{~nm}$ was assessed using microplate absorbance reader (Bio-Rad Laboratories, Hercules, CA, USA). All reactions were done in triplicate up to a final volume of $200 \mu \mathrm{l}$. Thiourea was used as a reference urease inhibitor.

\subsection{Cytotoxicity assay}

Murine 3T3-L1 cells were seeded at a density of $2.5 \times 10^{4}$ cells per well into 96well plates until confluent in Dulbecco's modified Eagle's medium (DMEM) containing low glucose $(1000 \mathrm{mg} / \mathrm{L}), 10 \%$ Fetal bovine serum (FBS), penicillin (100 units/mL) and streptomycin $(100 \mu \mathrm{g} / \mathrm{mL})$. The cells were incubated in a humidified atmosphere containing $5 \% \mathrm{CO}_{2}$ in air at $37^{\circ} \mathrm{C}$. Two days post-confluent, differentiation was induced by replacing the medium with differentiation medium [DMEM (high glucose: 4500 $\mathrm{mg} / \mathrm{L})$ supplemented with $10 \% \mathrm{FBS}, 1 \mu \mathrm{M}$ dexamethasone, $0.5 \mathrm{mM}$ IBMX, and 5 $\mu \mathrm{g} / \mathrm{mL}$ insulin]. Three days later, the differentiation medium was replaced with a maintenance medium [DMEM (high glucose) supplemented with 10\% FBS and 5 $\mu \mathrm{g} / \mathrm{mL}$ insulin]. After 2 days (on day 6), the medium was replaced by fresh medium, and the cells were cultured for a further 2 days.

On day 8 (post confluent), serial dilutions of our synthesized hybrids (12.5-100 $\mu \mathrm{g} / \mathrm{ml}$ ) were added to each well. Two days later, MTT reagent was added and the plates were incubated in a $\mathrm{CO}_{2}$ incubator at $37^{\circ} \mathrm{C}$ for $2 \mathrm{~h}$. The amount of formazan dye was measured spectrophotometrically at $590 \mathrm{~nm}$ using microplate absorbance reader (BioRad Laboratories, Hercules, CA, USA) (Mourad et al., 2020).

\subsection{Molecular docking}

Molecular docking study of the synthesized hybrids (10a-j) as well as the reference compound, thiourea, were performed using MOE software. Ligands were built into the builder interface of the MOE program and their energies were minimized until a RMSD (root mean square deviations) gradient of $0.01 \mathrm{kcal} / \mathrm{mol}$ and RMS (Root Mean Square) distance of $0.1 \AA$ with MMFF94× (Merck molecular force field 94×) force-field and the partial charges were automatically calculated. The X-ray crystallographic structure of urease protein (PDB code: 4UBP, resolution $2.25 \AA$ ), was downloaded from protein data bank (www.rcsb.org). The enzyme was prepared, the hydrogens were added as well as the atoms connection and type were checked with automatic correction. 
The obtained poses were studied and the poses which showed the best ligand-enzyme interactions were selected and stored for energy calculations.

\subsection{Pharmacokinetic properties prediction}

Pharmacokinetic properties as well as the drug-like nature of the synthesized hybrids (10a-j) were calculated and predicted based on online pkCSM software via the link, http://biosig.unimelb.edu.au/pkcsm/prediction .

\subsection{Statistical analysis}

Results were expressed as means \pm standard error of the mean (SEM) and were analyzed using GraphPad Prism ${ }^{\circledR}$ (GraphPad Software, San Diego California USA).

\section{Chemistry}

The target hybrids (10a-j) in Scheme 1 were synthesized in our laboratories and experienced significant DPP-4 inhibitory activity. The full details of their synthesis, spectroscopic as well as the elemental characterization can be found in our recent previous publication (Mourad et al., 2021).

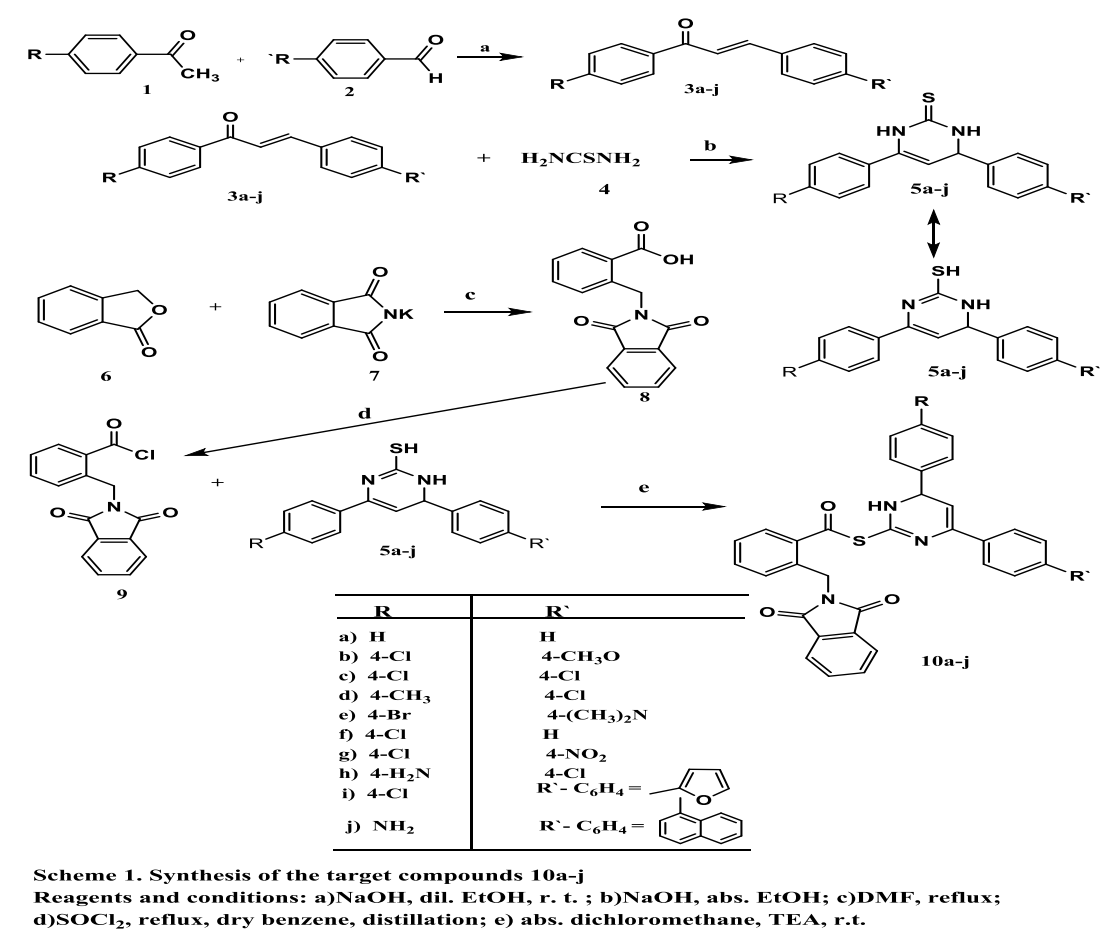

\section{Results}

\subsection{In vitro urease inhibition}

The synthesized hybrids (10a-j) were evaluated for their in vitro urease inhibitory activity. Table 1 and Figure 3 showed that $10 \mathrm{~g}, 10 \mathrm{e}, 10 \mathrm{~h}, 10 \mathbf{i}$ and $10 \mathbf{j}$ hybrids exhibited potent urease inhibition with $\mathrm{IC}_{50}$ values of $12.6 \pm 0.1,15.2 \pm 0.7,15.8 \pm 0.5$, 
$17.4 \pm 1.1$ and $20.1 \pm 1.3 \mu \mathrm{M}$, respectively, much better than thiourea, the reference urease inhibitor with $\mathrm{IC}_{50}$ value of $21.0 \pm 0.1 \mu \mathrm{M}$. Compared to thiourea, 10b hybrid showed slightly lower urease inhibitory activity with $\mathrm{IC}_{50}$ value of $28.2 \pm 2.1 \mu \mathrm{M}$. Moreover, 10f and 10d hybrids almost had similar urease inhibitory activity with $\mathrm{IC}_{50}$ values of $37.5 \pm 2.6$ and $38.7 \pm 1.9 \mu \mathrm{M}$, respectively. Among the synthesized hybrids, 10c and 10a hybrids showed the weakest urease inhibitory activity with $\mathrm{IC}_{50}$ values of $44.3 \pm 0.8$ and $56.4 \pm 2.2 \mu \mathrm{M}$, respectively.

Table 1: Urease inhibitory activity $\left(\mathrm{IC}_{50}\right)$ of $(\mathbf{1 0 a}-\mathbf{j})$ hybrids and thiourea.

\begin{tabular}{|c|c|}
\hline Compound No. & IC $_{\mathbf{5 0}} \pm \mathbf{S E M}(\boldsymbol{\mu M})$ \\
\hline $\mathbf{1 0 a}$ & $56.4 \pm 2.2$ \\
\hline $\mathbf{1 0 b}$ & $28.2 \pm 2.1$ \\
\hline $\mathbf{1 0 c}$ & $44.3 \pm 0.8$ \\
\hline $\mathbf{1 0 d}$ & $38.7 \pm 1.9$ \\
\hline $\mathbf{1 0 e}$ & $15.2 \pm 0.7$ \\
\hline $\mathbf{1 0 f}$ & $37.5 \pm 2.6$ \\
\hline $\mathbf{1 0 g}$ & $12.6 \pm 0.1$ \\
\hline $\mathbf{1 0 h}$ & $15.8 \pm 0.5$ \\
\hline $\mathbf{1 0}$ & $17.4 \pm 1.1$ \\
\hline $\mathbf{1 0 j}$ & $20.1 \pm 1.3$ \\
\hline Thiourea & $21.0 \pm 0.1$ \\
\hline
\end{tabular}

Data were expressed as mean \pm standard error of mean (SEM) of three independent experiments.

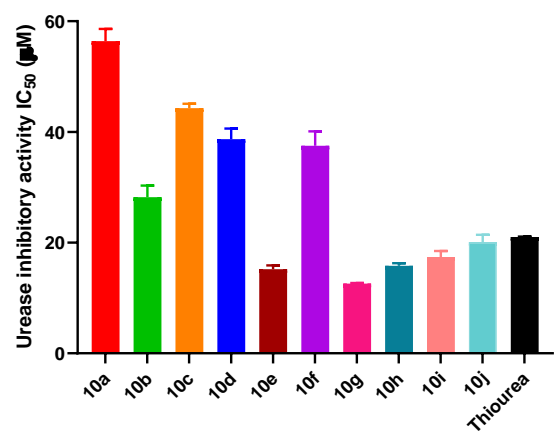

Figure 3: Urease inhibitory activity $\left(\mathrm{IC}_{50}\right)$ of $(\mathbf{1 0 a}-\mathbf{j})$ hybrids and thiourea

Data were expressed as mean \pm standard error of mean (SEM) of three independent experiments.

\subsection{Cytotoxicity assay}

The cytotoxicity of the synthesized hybrids (10a-j) was evaluated in 3T3-L1 cells. Fortunately, all compounds showed non-toxic behavior as evident by their high $\mathrm{IC}_{50}$ values that ranged from $19.6 \pm 1.5$ to $55.3 \pm 1.8 \mu \mathrm{M}$ compared to the standard cyclohexamide with $\mathrm{IC}_{50}$ value of $0.46 \pm 0.2 \mu \mathrm{M}$ (Table 2 and Figure 4). 
Table 2: Cytotoxicity assay of (10a-j) hybrids and Cyclohexamide.

\begin{tabular}{|c|c|}
\hline Compound No. & IC $_{\mathbf{5 0}} \mathbf{\pm S E M}(\boldsymbol{\mu M})$ \\
\hline $\mathbf{1 0 a}$ & $34.6 \pm 2.1$ \\
\hline $\mathbf{1 0 b}$ & $41.1 \pm 2.7$ \\
\hline $\mathbf{1 0 c}$ & $55.3 \pm 1.8$ \\
\hline $\mathbf{1 0 d}$ & $19.6 \pm 1.5$ \\
\hline $\mathbf{1 0 e}$ & $52.7 \pm 3.4$ \\
\hline $\mathbf{1 0 f}$ & $36.9 \pm 1.1$ \\
\hline $\mathbf{1 0 g}$ & $50.2 \pm 2.8$ \\
\hline $\mathbf{1 0 h}$ & $47.8 \pm 3.1$ \\
\hline $\mathbf{1 0}$ & $51.5 \pm 1.7$ \\
\hline $\mathbf{1 0 j}$ & $27.8 \pm 2.3$ \\
\hline Cyclohexamide & $0.46 \pm 0.2$ \\
\hline
\end{tabular}

Data were expressed as mean \pm standard error of mean (SEM) of three independent experiments.



Figure 4: Cytotoxicity assay of (10a-j) hybrids and Cyclohexamide.

Data were expressed as mean \pm standard error of mean (SEM) of three independent experiments.

\subsection{Molecular docking study}

\section{Docking at urease active site}

In order to explore the possible binding modes of the synthesized hybrids ( 10 aj) with their respective target protein, molecular docking study was carried out using MOE program where the 3D structure of the urease active sites is available at RCSB Protein Data Bank, [PDB code: 4UBP, resolution $2.25 \AA$ (www.rcsb.org)]. Thiourea was used as a reference compound. Table 3, showed the energy binding scores and binding interactions of the titled hybrids (10a-j). Importantly, the results cleared that nearly most of the synthesized hybrids were successfully docked into urease protein 
and achieved energy binding scores higher than thiourea. Moreover, they had significant binding interactions with the urease active sites such as, Ala 366, Ala 170, Asp 363, Cys 322, His 222, His 275 and $\mathrm{Ni}$ ion which explained their potential urease inhibitory activity (Ansari et al., 2009).

Notably, 10g hybrid possessed the highest binding energy score and the highest urease inhibitory activity where it has similar interaction pattern to the reference compound and consequently good fitting with the receptor active sites. However, $\mathbf{1 0 g}$ hybrid is engaged in network interactions with $\mathrm{Ni} 798$ of protein and formed strong hydrogen bonding interactions with Ala 170, Cys 322 and His 222 residues. Additionally, Ni 798 and Ni 799 are further coordinated by His 249, His 275, KCX 220, Asp 363, His 137 and His 139 residues, as shown in (Figure 5 C\&D).

Similarly, 10e hybrid formed strong hydrogen bonding interactions with the key amino acids residues in the binding sites which positively affected its in vitro urease inhibitory activity. The bromine atom, sulphur atom and the free $\mathrm{NH}$ group in the dihydropyrimidine ring of this compound interact by three hydrogen bonds with Ala 366 and His 275. As well as, Ni 798 and Ni 799 bonded with KCX 220, His 249, His 275, His 137, His 139 and Asp 363 (Figure 5 A\&B).

Of considerable interest, the binding mode showed that the sulphur atom, nitrogen atom, free $\mathrm{NH}$, carbonyl oxygen and the methylene group of $\mathbf{1 0 h}$ hybrid participated by six hydrogen bonding network with Ala 366, Cys 322, Lys 169, Leu 365 and Gly 280 residues. Additionally, Ni 798 and Ni 799 further bonded with KCX 220, His 249, His 275, His 137, His 139 and Asp 363 (Figure 5 E\&F). On the other hand, Ala 366 residue formed strong hydrogen bond with sulphur atom of 10i hybrid in addition to another $\pi$-cation bond with Lys 169 .

However, the $\mathrm{IC}_{50}$ values of $\mathbf{1 0 b}$ and $\mathbf{1 0 d}$ hybrids were less than that of thiourea which may be attributed to the formation of weak $\pi$-hydrogen bonding interactions with the key amino acid Ala 170, beside another hydrogen bonds and $\pi$-cation bonding interaction with Asp 224 and Lys 169 residues. Notably, the electron withdrawing effect of chlorine atom negatively affected the $\mathrm{IC}_{50}$ values of $10 \mathrm{c}$ and $10 \mathrm{f}$ hybrids which could be explained by the formation of weak $\pi$-hydrogen bonding interactions between the phenyl rings of these compounds and Ala 170, Asp 224, Glu 166, Lys 169 and His 323 residues. Additionally, another hydrogen bond formed between the chlorine atom of 10c hybrid and Gly 280 residue.

In the same context, the unsubstituted 10a hybrid lost its urease inhibitory activity owing to the formation of only one weak $\pi$-hydrogen bonding interaction with Ala 170 residue. Finally, it can be concluded that most of the synthesized hybrids are able to interact with the crucial amino acids in the urease protein and thus are able to inhibit its activity efficiently. 
Table 3: Types of binding interactions and energy scores $(\mathrm{kcal} / \mathrm{mol})$ for $(\mathbf{1 0 a}-\mathbf{j})$ hybrids and thiourea at the urease active site.

\begin{tabular}{|c|c|c|}
\hline $\begin{array}{l}\text { Compound } \\
\text { No. }\end{array}$ & Types pf Interactions & $\begin{array}{l}\text { Energy } \\
\text { Scores }\end{array}$ \\
\hline $\mathbf{1 0 a}$ & - One $\pi$-hydrogen bonding interaction with Ala 170 (4.11 $\AA$ ). & -5.90 \\
\hline $10 \mathrm{~b}$ & $\begin{array}{l}\text { - One hydrogen bonding interaction with Asp } 224(2.99 \AA) \text {. } \\
\text { - Two } \pi \text {-hydrogen bonding interaction with Ala } 170 \text { and Asp } 224 \text { (4.20 and } \\
3.99 \AA \text { ). }\end{array}$ & -6.69 \\
\hline 10c & $\begin{array}{l}\text { - One hydrogen bonding interaction with Gly } 280(3.85 \AA) \text {. } \\
\text { - Two } \pi \text {-hydrogen bonding interaction with Ala } 170 \text { and Asp } 224 \text { ( } 3.81 \text { and } \\
4.41 \AA) \text {. } \\
\text { - One } \pi \text {-cation bonding interaction with Lys } 169(4.11 \AA) \text {. } \\
\text {-Ni } 798 \text { bonded to KCX } 220 \text {, His } 249 \text { and His } 275(1.95,1.96 \text { and } 2.03 \AA) \text {. }\end{array}$ & -6.46 \\
\hline 10d & $\begin{array}{l}\text {-Two } \pi \text {-hydrogen bonding interaction with Ala } 170 \text { and Asp } 224(3.80 \text { and } \\
4.22 \AA) \text {. } \\
\text { - One } \pi \text {-cation bonding interaction with Lys } 169(4.27 \AA) \text {. } \\
\text { - Ni bonded to KCX } 220 \text {, His } 249 \text { and His } 275(1.95,1.96 \text { and } 2.03 \AA) \text {. }\end{array}$ & -6.47 \\
\hline 10e & $\begin{array}{l}\text { - Two hydrogen bonding interaction with Ala } 366(3.49 \text { and } 2.98 \AA) \text {. } \\
\text { - One hydrogen bonding interaction with His } 275(3.32 \AA) \text {. } \\
\text { - Ni } 798 \text { bonded with KCX } 220 \text {, His } 249 \text { and His } 275(1.95,1.96 \text { and } 2.03 \\
\AA) \text {. } \\
\text { - Ni } 799 \text { bonded with His } 137 \text {, His } 139 \text {, Asp } 363 \text { and KCX } 220(1.99,1.99 \text {, } \\
2.04 \text { and } 2.07 \AA) \text {. } \\
\text { - Ni } 799 \text { bonded with two ionic bonds with Asp } 363 \text { and His } 137(2.07 \text { and } \\
1.99 \AA) \text {. }\end{array}$ & -6.45 \\
\hline $10 f$ & $\begin{array}{l}\text { - Three } \pi \text {-hydrogen bonding interaction with Glu } 166 \text {, Lys } 169 \text { and His } 323 \\
(4.08,4.27 \text { and } 3.59 \AA) \text {. }\end{array}$ & -6.63 \\
\hline $10 \mathrm{~g}$ & $\begin{array}{l}\text {-One metallic interaction with Ni } 798(2.84 \AA) \text {. } \\
\text { - Two hydrogen bonding interaction with Cys } 322 \text { and His } 222(3.26,3.36 \\
\AA \text { ). } \\
\text { - Ni } 798 \text { bonded with KCX } 220 \text {, His } 249 \text { and His } 275(1.95,1.96 \text { and } 2.03 \\
\AA) \text {. } \\
\text { - One } \pi \text {-hydrogen bonding interaction with Ala } 170(4.11 \AA) \text {. } \\
\text { - Ni } 799 \text { bonded with metallic bonds with His } 137 \text {, His } 139, \mathrm{KCX} 220 \text { and } \\
\text { Asp } 363 \text { (1.99, } 1.99,2.04 \text { and } 2.07 \AA) \text {. } \\
\text { - Ni } 799 \text { bonded with two ionic bonds with Asp } 363 \text { and His } 137(2.07 \text { and } \\
1.99 \AA) \text {. }\end{array}$ & -7.29 \\
\hline 10h & $\begin{array}{l}\text { - Six hydrogen bonding interaction with Ala } 366 \text {, Cys 322, Lys 169, Leu } 365 \\
\text { and Gly } 280(2.91,3.98,3.44,3.24,3.93 \text { and } 2.85 \AA) \text {. } \\
\text { - Ni } 798 \text { bonded with metallic bonds with KCX } 220 \text {, His } 249 \text { and His } 275 \\
(1.95,1.96 \text { and } 2.03 \AA) \\
\text { - Ni } 799 \text { bonded with metallic and ionic bonds with KCX 220, Asp } 363 \text {, His } \\
137 \text { and His } 139(2.04,2.07,1.99 \text { and } 2.07 \AA)\end{array}$ & -6.52 \\
\hline 10i & $\begin{array}{l}\text { - One hydrogen bonding interaction with Ala } 366(3.24 \AA) \text {. } \\
\text { - One } \pi \text {-cation bonding interaction with Lys } 169 \text { (4.01 } \AA \text { ). }\end{array}$ & -6.45 \\
\hline $\mathbf{1 0 j}$ & $\begin{array}{l}\text { - One hydrogen bonding interaction with Asp } 332(3.62 \AA) \text {. } \\
\text { - Two } \pi \text {-hydrogen bonding interaction with Ala } 170 \\
(4.05 \text { and } 4.15 \AA) \text {. }\end{array}$ & -6.39 \\
\hline Thiourea & $\begin{array}{l}\text { - Two hydrogen bonding interaction with Ala } 170 \text { and His } 222 \text { (3.05 and } \\
3.80 \AA) \text {. } \\
\text { - Two metallic interaction with Ni } 798 \text { and Ni } 799 \text { (2.33 and } 2.80 \AA) \text {. }\end{array}$ & -5.02 \\
\hline
\end{tabular}



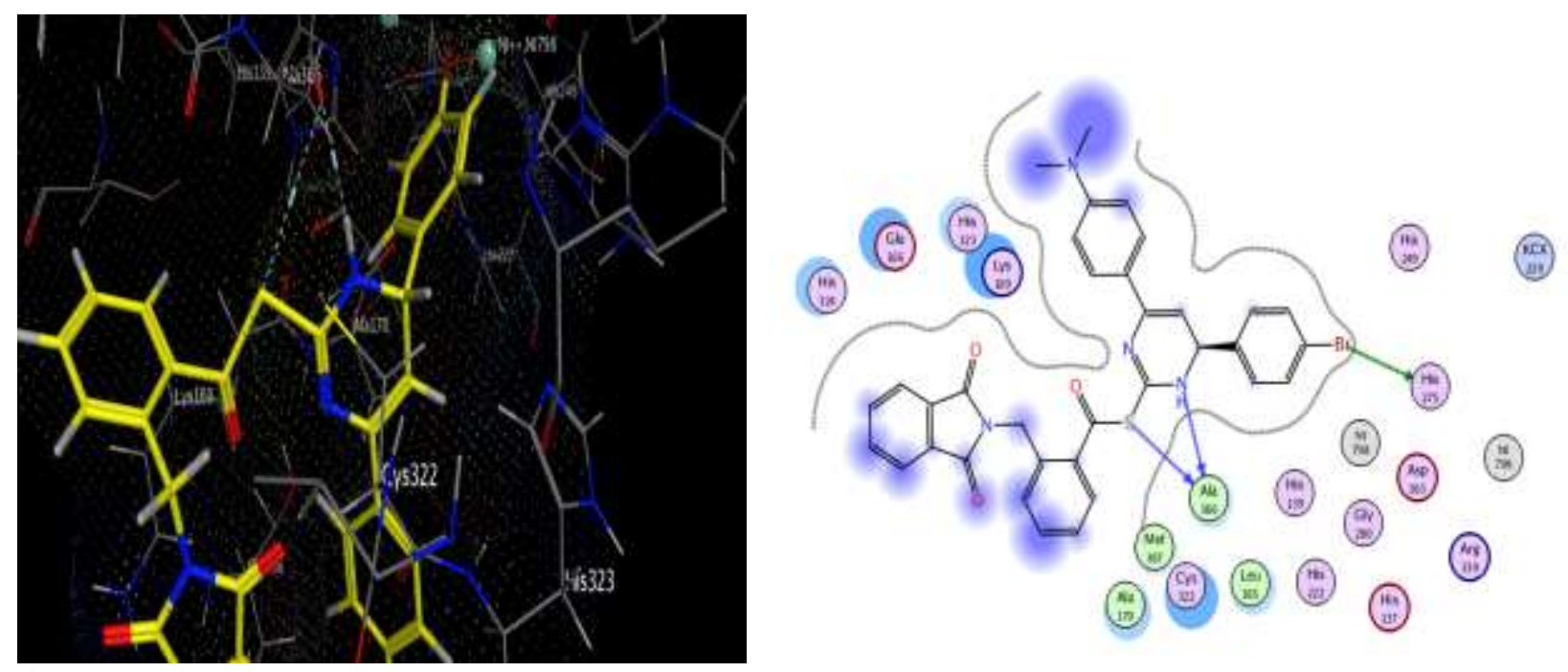

A

B
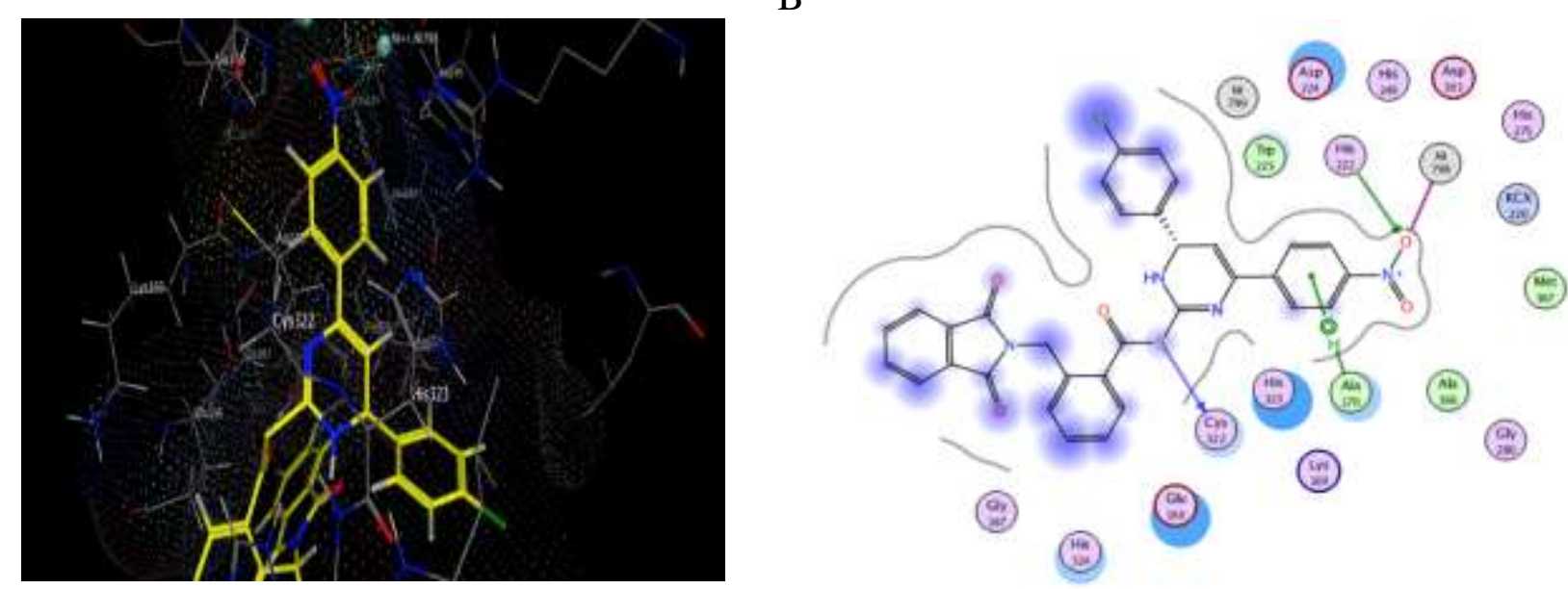

C

D
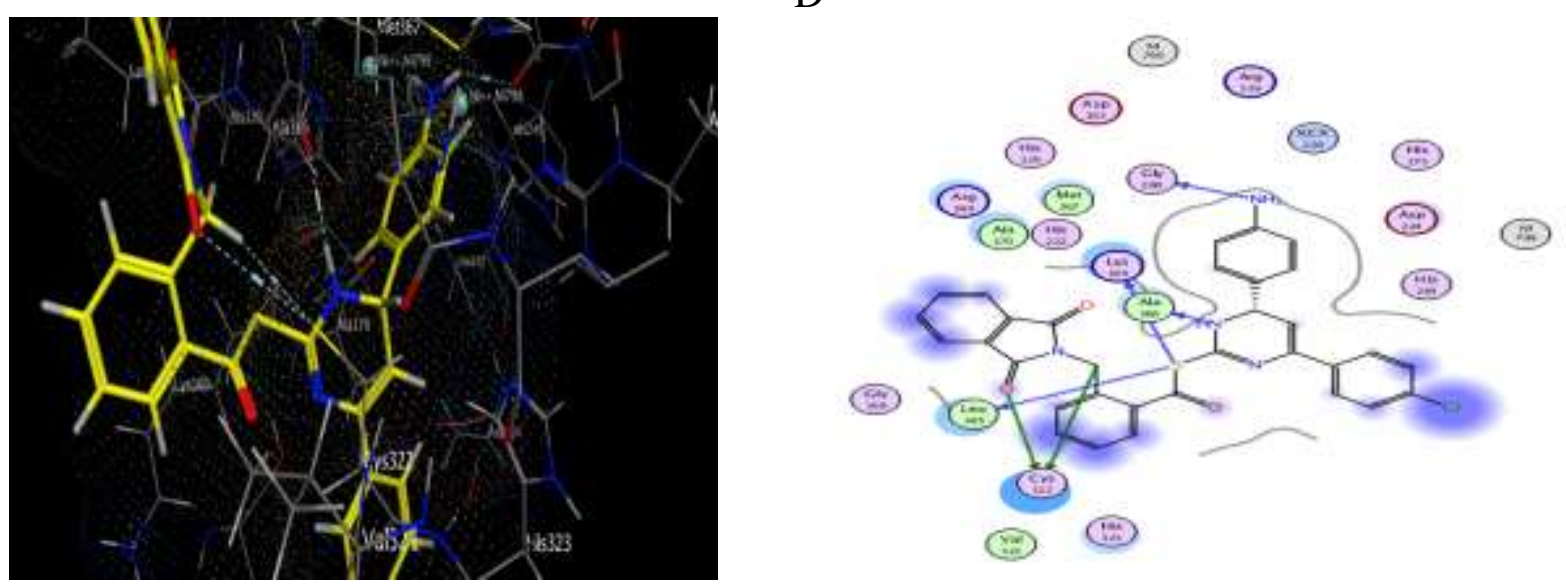

E

F 

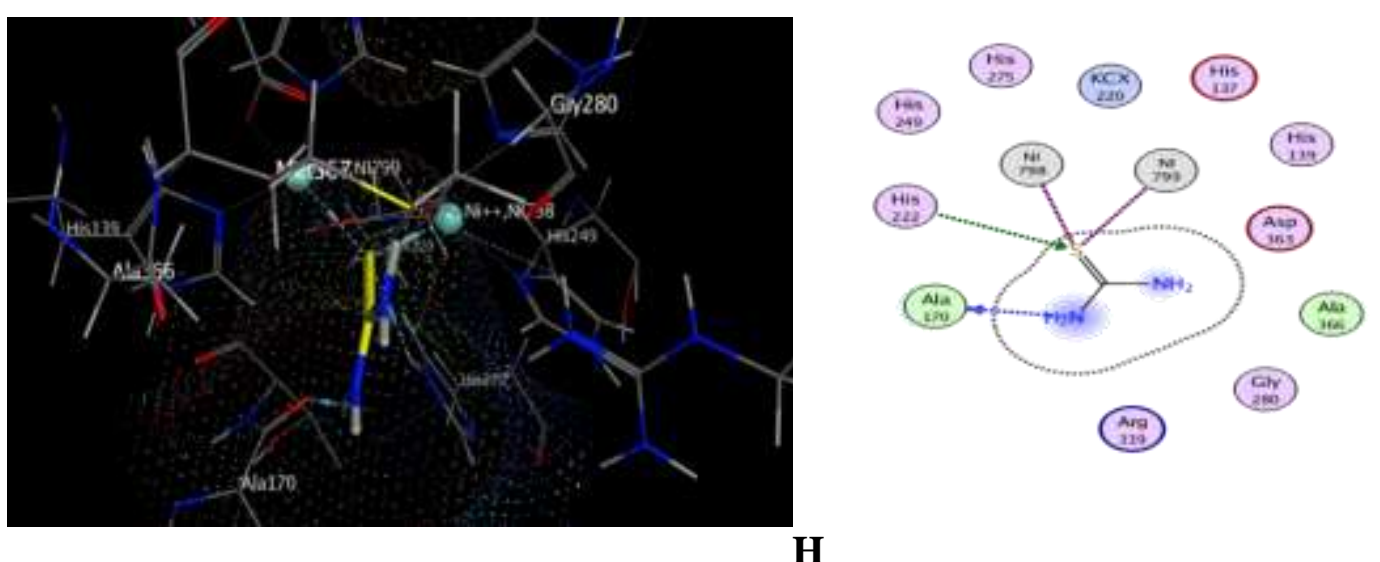

G

Figure 5. Docking and binding pattern of compounds $10 \mathrm{e}, 10 \mathrm{~g}, 10 \mathrm{~h}$ and thiourea showing interactions with different amino acid residues found in the urease active site (PDB code: 4UBP).

(A) 3D structure of compound 10e (yellow) (B) 2D structure of compound 10e.

(C) 3D structure of compound $\mathbf{1 0 g}$ (yellow) (D) 2D structure of compound $\mathbf{1 0 g}$.

(E) 3D structure of compound $\mathbf{1 0 h}$ (yellow) (F) 2D structure of compound 10h. (G) 3D structure of thiourea (yellow) $(\mathrm{H}) 2 \mathrm{D}$ structure of thiourea.

\subsection{In silico ADMET prediction}

Pharmacokinetics are complex processes that constitute the effect of the body on the administrated drug. Pharmacokinetics start by absorption and distribution steps and end by process of disposition that involves metabolism and excretion. The pharmacokinetic profile of the synthesized hybrids (10a-j) was predicted using pkCSM pharmacokinetic prediction program.

\subsubsection{Absorption studies}

Several pharmacokinetic parameters that could affect absorption rate were evaluated for the synthesized hybrids. Among the calculated parameters, water solubility, human intestinal absorption (HIA), Caco-2 cell permeability, being a Pglycoprotein substrate or I/II inhibitor.

According to the results presented in Table 4, synthesized hybrids (10a-j) had moderate water solubility that positively reflected on distribution. Additionally, Caco-2 permeability results predicted significant in vivo absorption rate via small intestine. Consequently, the synthesized compounds exhibited high HIA values that ranged from $86.56 \%$ to $100 \%$ which indicated that the synthesized hybrids have good oral bioavailability. Furthermore, (10a-j) hybrids act as P-glycoprotein substrate as well as P-glycoprotein I/II inhibitors. 
Table 4: Absorption properties of the synthesized hybrids (10a-j).

\begin{tabular}{|l|c|c|c|c|c|c|c|c|c|c|}
\hline \multicolumn{1}{|c|}{ Property } & $\mathbf{1 0 a}$ & $\mathbf{1 0 b}$ & $\mathbf{1 0 c}$ & $\mathbf{1 0 d}$ & $\mathbf{1 0 e}$ & $\mathbf{1 0 f}$ & $\mathbf{1 0 g}$ & $\mathbf{1 0 h}$ & $\mathbf{1 0 i}$ & $\mathbf{1 0 j}$ \\
\hline $\begin{array}{l}\text { Water } \\
\text { solubility }\end{array}$ & -4.97 & -4.84 & -4.89 & -4.95 & -4.72 & -4.99 & -4.47 & -4.06 & -4.74 & -3.94 \\
\hline $\begin{array}{l}\text { Caco2 } \\
\text { permeabili } \\
\text { ty }\end{array}$ & 0.43 & 0.54 & 0.47 & 0.52 & 0.55 & 0.45 & 0.22 & 0.59 & 0.76 & 0.43 \\
\hline $\begin{array}{l}\text { Human } \\
\text { intestinal } \\
\text { absorption } \\
\text { (\%absorbe } \\
\text { d) }\end{array}$ & 89.38 & 89.03 & 86.56 & 88.01 & 89.29 & 87.98 & 100 & 97.87 & 100 & 100 \\
\hline $\begin{array}{l}\text { Skin } \\
\text { permeabili } \\
\text { ty }\end{array}$ & -2.73 & -2.73 & -2.73 & -2.73 & -2.73 & -2.73 & -2.73 & -2.74 & -2.74 & -2.74 \\
\hline $\begin{array}{l}\text { P- } \\
\text { glycoprotei } \\
\text { n substrate }\end{array}$ & Yes & Yes & yes & Yes & Yes & Yes & Yes & Yes & Yes & Yes \\
\hline $\begin{array}{l}\text { P- } \\
\text { glycoprotei } \\
\text { n I } \\
\text { inhibitor }\end{array}$ & Yes & Yes & Yes & Yes & Yes & Yes & Yes & Yes & Yes & Yes \\
\hline $\begin{array}{l}\text { P- } \\
\text { glycoprotei } \\
\text { n II } \\
\text { inhibitor }\end{array}$ & Yes & Yes & Yes & Yes & Yes & Yes & Yes & Yes & Yes & Yes \\
\hline
\end{tabular}

\subsubsection{Distribution studies}

Parameters that affect distribution of our synthesized hybrids (10a-j) including volume of distribution $V_{d}$, blood brain barrier penetration (BBB) and plasma protein binding (PPB) were calculated. As shown in Table 5, all the synthesized hybrids have acceptable $V_{d}$, poor BBB and CNS permeability.

Table 5: Distribution properties of the synthesized hybrids (10a-j).

\begin{tabular}{|l|c|c|c|c|c|c|c|c|c|c|}
\hline Property & $\mathbf{1 0 a}$ & $\mathbf{1 0 b}$ & $\mathbf{1 0 c}$ & $\mathbf{1 0 d}$ & $\mathbf{1 0 e}$ & $\mathbf{1 0 f}$ & $\mathbf{1 0 g}$ & $\mathbf{1 0 h}$ & $\mathbf{1 0 i}$ & $\mathbf{1 0 j}$ \\
\hline $\begin{array}{l}\text { VDss } \\
\text { (human) }\end{array}$ & -0.51 & -0.46 & -0.39 & -0.39 & -0.32 & -0.45 & -0.75 & -0.57 & -0.11 & -1.16 \\
\hline $\begin{array}{l}\text { Fraction } \\
\text { unbound } \\
\text { (human) }\end{array}$ & 0 & 0 & 0 & 0 & 0 & 0 & 0.007 & 0.005 & 0 & 0.103 \\
\hline $\begin{array}{l}\text { BBB } \\
\text { permeabili } \\
\text { ty }\end{array}$ & -0.002 & -0.38 & -0.34 & -0.17 & -0.29 & -0.17 & -0.64 & -0.92 & -0.38 & -0.92 \\
\hline $\begin{array}{l}\text { CNS } \\
\text { permeabili } \\
\text { ty }\end{array}$ & -1.39 & -1.47 & -1.16 & -1.20 & -1.35 & -1.27 & -1.51 & -1.42 & -1.42 & -1.33 \\
\hline
\end{tabular}




\subsubsection{Metabolism and excretion studies:}

With regard to liver microsomal enzymes, the calculated data showed that almost all hybrids (10a-i) are neither substrate nor inhibitor of CYP2D6. On contrary, all synthesized hybrids (10a-i) are CYP3A4 substrates and inhibitors (except 10j). Similarly, all synthesized hybrids were found to be CYP2C19 inhibitors. Meanwhile, 10a, 10f and 10h-10j hybrids were considered as CYP1A2 inhibitors. Regarding CYP2C9, 10a, 10b, 10h and 10i hybrids were classified as inhibitors. (Table 6).

Finally, the synthesized hybrids (10a-j) exhibited an acceptable clearance rate

Table 6: Metabolism and excretion properties of the synthesized hybrids (10a-i).

\begin{tabular}{|l|c|c|c|c|c|c|c|c|c|c|}
\hline \multicolumn{1}{|c|}{ Property } & $\mathbf{1 0 a}$ & $\mathbf{1 0 b}$ & $\mathbf{1 0 c}$ & $\mathbf{1 0 d}$ & $\mathbf{1 0 e}$ & $\mathbf{1 0 f}$ & $\mathbf{1 0 g}$ & $\mathbf{1 0 h}$ & $\mathbf{1 0 i}$ & $\mathbf{1 0 j}$ \\
\hline CYP2D6 substrate & No & No & No & No & No & No & No & No & No & Yes \\
\hline CYP3A4 substrate & Yes & Yes & Yes & Yes & Yes & Yes & Yes & Yes & Yes & Yes \\
\hline CYP1A2 inhibitor & Yes & No & No & No & No & Yes & No & Yes & Yes & Yes \\
\hline CYP2C19 inhibitor & Yes & Yes & Yes & Yes & Yes & Yes & Yes & Yes & Yes & Yes \\
\hline CYP2C9 inhibitor & Yes & Yes & No & No & No & No & No & Yes & Yes & No \\
\hline CYP2D6 inhibitor & No & No & No & No & No & No & No & No & No & No \\
\hline CYP3A4 inhibitor & Yes & Yes & Yes & Yes & Yes & Yes & Yes & Yes & Yes & No \\
\hline Total Clearance & 0.02 & -0.13 & -0.19 & -0.11 & -0.09 & -0.11 & -1.51 & -0.28 & -0.06 & -0.19 \\
\hline $\begin{array}{l}\text { Renal OCT2 } \\
\text { substrate No }\end{array}$ & No & No & No & No & No & No & No & No & No \\
\hline
\end{tabular}

\subsubsection{Toxicity studies}

AMES test is used to predict the mutagenic potential of the investigated compounds. Fortunately, all synthesized hybrids lack mutagenic potential, as shown in Table 7.

Table 7: Toxicity properties of the synthesized hybrids (10a-i).

\begin{tabular}{|l|c|c|c|c|c|c|c|c|c|c|}
\hline \multicolumn{1}{|c|}{ Property } & $\mathbf{1 0 a}$ & $\mathbf{1 0 b}$ & $\mathbf{1 0 c}$ & $\mathbf{1 0 d}$ & $\mathbf{1 0}$ & $\mathbf{1 0 f}$ & $\mathbf{1 0 g}$ & $\mathbf{1 0 h}$ & $\mathbf{1 0 i}$ & $\mathbf{1 0 j}$ \\
\hline AMES toxicity & No & No & No & No & No & No & No & No & No & No \\
\hline $\begin{array}{l}\text { Max. tolerated } \\
\text { dose (human) } \\
\text { (log mg/kg/day) }\end{array}$ & 0.08 & -0.10 & -0.01 & -0.01 & -0.02 & 0.03 & -0.07 & 0.15 & -0.06 & 0.30 \\
\hline hERG I inhibitor & No & No & No & No & No & No & No & No & No & No \\
\hline $\begin{array}{l}\text { hERG II } \\
\text { inhibitor }\end{array}$ & Yes & Yes & Yes & Yes & Yes & Yes & Yes & Yes & Yes & Yes \\
$\begin{array}{l}\text { Oral Rat Acute } \\
\text { Toxicity (LD50) } \\
\text { (mol/kg) }\end{array}$ & 2.59 & 2.54 & 2.58 & 2.59 & 2.59 & 2.58 & 2.92 & 2.14 & 2.54 & 2.54 \\
\hline $\begin{array}{l}\text { Oral Rat Chronic } \\
\text { Toxicity(LOAEL } \\
\text { )(logmg/kg/day) }\end{array}$ & 2.16 & 1.99 & 2.03 & 1.99 & 1.96 & 2.10 & 2.67 & 2.09 & 1.49 & 3.54 \\
\hline $\begin{array}{l}\text { Hepatotoxicity } \\
\text { Yes }\end{array}$ & Yes & Yes & No & No & Yes & Yes & Yes & No & Yes \\
\hline $\begin{array}{l}\text { Skin } \\
\text { Sensitization }\end{array}$ & No & No & No & No & No & No & No & No & No & No \\
\hline
\end{tabular}




\subsubsection{Drug-likeness Characters}

Scores of drug-likeness of all synthesized hybrids (10a-j) are presented in Table 8. Notably, compound with zero or negative score is lacking drug -likeness. Interestingly, 10b, 10d, 10h, 10c, 10f and 10i hybrids have the highest drug-likeness scores that ranged from 1.07 to 0.87 . On the other hand, 10a hybrid had the lowest druglikeness score (0.25).

Finally, it can be concluded that the synthesized hybrids are likely to be orally active, having good intestinal absorption, having poor BBB and CNS permeability, lacking mutagenic potential as well as they possessed promising drug likeness characteristics.

Table 8: Prediction of drug-likeness model score of the synthesized hybrids (10a-i).

\begin{tabular}{|c|c|}
\hline Compound no. & Drug-likeness model score by MolSoft \\
\hline $\mathbf{1 0 a}$ & 0.25 \\
\hline $\mathbf{1 0 b}$ & 1.07 \\
\hline $\mathbf{1 0 c}$ & 0.89 \\
\hline $\mathbf{1 0 d}$ & 0.95 \\
\hline $\mathbf{1 0 e}$ & 0.58 \\
\hline $\mathbf{1 0 f}$ & 0.89 \\
\hline $\mathbf{1 0 g}$ & 0.65 \\
\hline $\mathbf{1 0 h}$ & 0.95 \\
\hline $\mathbf{1 0} \mathbf{1 0}$ & 0.87 \\
\hline $\mathbf{1 0}$ & 0.53 \\
\hline
\end{tabular}

\section{Discussion}

The present study aimed at synthesizing dihydropyrimidine phthalimide hybrids and evaluating their in vitro urease inhibitory activity. We focused our design on molecular modification of substituents in the para-position of aromatic rings in positions 4 and 6 of 1,6-dihydropyrimidines moiety as well as the size and type of this substituents. The results showed in Table 1 indicated that $\mathbf{1 0 g}$ hybrid exhibited the most potent urease inhibitory activity among the other synthesized hybrids with $\mathrm{IC}_{50}$ value of $(12.6 \pm 0.1 \mu \mathrm{M})$, much better than thiourea, the reference urease inhibitor, with $\mathrm{IC}_{50}$ value of $(21.0 \pm 0.1 \mu \mathrm{M})$. This behavior may be attributed to the ionic character of the $p$-nitro group that markedly enhances its binding pattern with nickel ion and with the key amino acids present in the receptor active site.

Moreover, compounds $10 \mathrm{e}$ and $\mathbf{1 0 h}$ possessed nearly equal urease inhibitory activity to that of $10 \mathrm{~g}$ hybrid; as indicated by their $\mathrm{IC}_{50}$ values $15.2 \pm 0.7,15.8 \pm 0.5$ $\mu \mathrm{M}$, respectively. Interestingly, despite the large size of both $p$-bromophenyl and $p$ dimethylaminophenyl groups in 10e hybrid, the electronegativity of the substituents played the major role in enhancing its binding mode with the active receptor site which consequently improved its urease inhibitory activity.

Additionally, the potent urease inhibitory activity of $\mathbf{1 0 h}$ hybrid may be owed to the presence of lone pair of electrons on the nitrogen atom which make it successfully 
able to form strong hydrogen bond network with the crucial amino acids in the active site. Furthermore, $\mathrm{IC}_{50}$ values of $\mathbf{1 0 i}$ and $\mathbf{1 0 j}$ hybrids were $(17.4 \pm 1.1$ and $20.1 \pm 0.1$ $\mu \mathrm{M})$, respectively, less than that of thioureae. The urease inhibitory activity of $\mathbf{1 0} \mathbf{i}$ hybrid backed to the small size of furanyl group which makes it more suitable for the fitting to the receptor active site. Also, the nitrogen lone pair of electrons of $\mathbf{1 0 j}$ hybrid enhances its binding to the receptor active sites and consequently supported the urease inhibitory activity.

However, the presence of lipophilic electron donating $p$-methoxyphenyl group positively reflected on urease inhibitory activity of $\mathbf{1 0 b}$ hybrid that has $\mathrm{IC}_{50}$ value slightly larger than $\mathrm{IC}_{50}$ value of thiourea. On the other hand, 10c and 10f hybrids exhibited weak binding interaction with the key amino acid residue in the receptor site that was evidenced by their high $\mathrm{IC}_{50}$ values $(44.3 \pm 0.8$ and $37.5 \pm 2.6 \mu \mathrm{M})$, respectively. Finally, the unsubstituted 10a hybrid experienced the lowest urease inhibitory activity $\left(\mathrm{IC}_{50}=56.4 \pm 2.2 \mu \mathrm{M}\right)$ which was also confirmed by its weak binding interaction with the receptor active site. Accordingly, it can be concluded that the nature of the substituents, lipophilicity, electronic nature as well as the steric factor greatly influenced the biological activity of the system incorporated.

Of considerable interest, the cytotoxicity results indicated that the synthesized hybrids (10a-j) were considered safe compared to the reference compound. Moreover, the molecular docking study showed that most of the synthesized hybrids bind efficiently to the key amino acids in the active receptor site which positively reflected on their urease inhibitory activity. In the same context, the performed pharmacokinetic study revealed that the synthesized hybrids have acceptable pharmacokinetic profile involving good oral bioavailability, distribution, intestinal absorption, no BBB permeability, no mutagenic potential and acceptable clearance rate. Finally, the synthesized hybrids have promising drug-likeness properties.

\section{Conclusion}

Novel series of dihydropyrimidine phthalimide (10a-j) has been synthesized and examined for their urease inhibitory activity. The results indicated that five hybrids $\mathbf{1 0 g}$, 10e, $10 \mathbf{h}, 10 \mathbf{i}$ and $\mathbf{1 0 j}$ exhibited superior urease inhibitory activity with $\mathrm{IC}_{50}$ range of $12.6 \pm 0.1$ to $20.1 \pm 1.3 \mu \mathrm{M}$, compared to thiourea with $\mathrm{IC}_{50}$ of $21.0 \pm 0.1 \mu \mathrm{M}$. Other synthesized hybrids showed moderate activity. The molecular docking study further supported our findings, with the most active compounds being fitted well with the crucial amino acids in the urease active sites. The structure activity relationship revealed that the nitro, amino and dimethylamino groups are favorable for the inhibitory activity. The pharmacokinetic study showed that most synthesized hybrids have high intestinal absorption, poor CNS permeability, no mutagenicity; as well as they achieved high scores in drug-likeness analysis. According to in vitro cytotoxicity assay, the synthesized hybrids considered safe. The novel synthesized urease inhibitors hybrids represent a promising safe and effective candidates that could provide a therapeutic add in the field of urease related pathologies. 


\section{REFERENCES}

Ansari, F.L., Wadood, A., Ullah, A., Iftikhar, F., Ul-Haq, Z., (2009). In silico studies of urease inhibitors to explore ligand-enzyme interations. J. Enzyme Inhib. Med. Chem. 24, 151-156. https://doi.org/10.1080/14756360801945598.

Bano, B., Khalid, K., Khan, M., Begum, F., Lodhib, M.A., Salara, U., Khalil, R., Ul-Haq, Z., Perveend, S., (2018). Benzylidine indane-1,3-diones: As novel urease inhibitors; synthesis, in vitro, and in silico studies. Bioorg. Chem. 81, 658-671. https://doi.org/10.1016/j.bioorg.2018.09.030.

Bayerdörffer, E., Ottenjann, R., (2009). The role of antibiotics in Scand. J. associated peptic ulcer disease. Gastroenterol. 23, 93-100. https://doi.org/10.3109/00365528809091721.

Collinand, C.M., Orazio, S.E.F.D., (1993). Bacterial ureases: structure, regulation of expression and role in pathogenesis. Mol. Micro. 9, 907-913. https://doi. 10.1111/j.1365-2958.1993.tb01220.x.

Gong, K., Wang, H., Wang, S., Ren, X., (2015). $\beta$-Cyclodextrin-propyl sulfonic acid: a new and eco-friendly catalyst for one-pot multi-component synthesis of 3,4dihydropyrimidones via Biginelli reaction. Tetrahedron. 71, 4830-4834. https://doi.org/10.1016/j.tet.2015.05.028.

Hameed, A., Anwar, A., Khan, K.M., Malik, R., Shahab, F., Siddiq, S., Basha, F.Z., Choudhary, M.I., (2013). Urease inhibition and anticancer activity of novel polyfunctional 5,6-dihydropyridine derivatives and their structureactivity relationship. Eur. J. Chem. 4, 49-52. https://doi.org/10.5155/eurjchem.4.1.49-52.701.

Hameed, A., Khan, K.M., Zehra, S.T., Ahmed, R., Shafiq, Z., Bakht, S.M., Yaqub, M., Hussain, M., Leon, A.D.L.V.D., Bajorath, F.N.J., Ahmad, H., Tahir, M.N., Choudhary, M.I., (2010). Synthesis, Biological evaluation and molecular docking of N-Phenylthiosemicarbazones as urease inhibitors, J. ACS. Med. Chem. Lett. 1, 145-149. https://doi.10.1016/j.bioorg.2015.06.004.

Hooi, J.K.Y., Lai, W.Y., Ng, W.K., Suen, M.M.Y., Underwood, F.E., Tanyingoh, D., Malfertheiner, P., Graham, D.Y., Wong, V.W.S., Wu, J.C.Y., Chan, F.K.L., Sung, J.J.Y., Kaplan, G.G., Ng, S.C., (2017). Global Prevalence of Helicobacter pylori Infection: Systematic Review and Meta-Analysis. Gastroenterol. 153, 420-429.https://doi.10.1053/j.gastro.2017.04.022.

Iftikhar, F., Ali, Y., Kiani, F.A., Hassan, S.F., Fatima, T., Khan, A., Niaz, B., Hassan, A., Ansari, F.L., Rashid, U., (2017). Design, synthesis, in vitro Evaluation and docking studies on dihydropyrimidine-based urease inhibitors. Bioorg. Chem. 74, 53-65. http://dx.doi.org/10.1016/j.bioorg.2017.07.003. 
Jr, R.M.P.; Blaser, M.J., (2002). Helicobacter pylori and gastrointestinal tract adenocarcinomas. Nat. Rev. Cancer 2, 28-37. https:// 10.1038/nrc703.

Khan, A., Hashim, J., Arshad, N., Khan, I., Siddiqui, N., Wadood, A., Ali, M., Arshad, F., Khan, K.M., Choudhary, M.I., (2016). Dihydropyrimidine based hydrazine dihydrochloride derivatives as potent urease inhibitors. Bioorg. Chem. 64, 85-96. https://doi.10.1016/j.bioorg.2015.12.007.

Krajewska, B., Ureases, I., (2009). Functional catalytic and kinetic properties: a review, J. Mol. Cat. B: Enzym. 59, 9-21. https://doi.org/10.1016/j.molcatb.2009.01.003.

Li, M., Ding, W., Baruah, B., Cransand, D.C., Wang, R., (2008). Inhibition of protein tyrosine phosphatase $1 \mathrm{~B}$ and alkaline phosphatase by bis (maltolato) oxovanadium (IV). J. Inorg. Biochem. 102, 1846-1853. doi: https://doi.10.1016/j.jinorgbio.2008.06.007.

Macomber, L., Minkara, M.S., Hausinger, M.R.P., Merz, K.M., (2015). Reduction of Urease Activity by Interaction with flap covering the active site. J. Chem. Inf. Model. 55, 354-361. https://doi.10.1021/ci500562t.

Mobley, H.L., Island, M.D., Hausinger, R.P., (1995). Molecular biology of microbial ureases. Microbiol. Rev. 59, 451-480. PMID: 7565414.

Mourad, A.A.E., Khodir, A.E., Saber, S., Mourad, M.A.E., (2021). Novel Potent and Selective DPP-4 Inhibitors: Design,Synthesis and Molecular Docking Study of Dihydropyrimidine Phthalimide Hybrids. Pharmaceuticals. 14, 144-168. https://doi.org/10.3390/ph14020144.

Mourad, A.A.E., Mourad, M.A.E., (2020). Enhancing insulin sensitivity by dual PPAR $\gamma$ partial agonist, $\beta$-catenin inhibitor: Design, synthesis of new aphthalimido-o-toluoyl2-aminothiazole hybrids. Life Sciences. 259, 118270118285. https://doi.org/10.1016/j.lfs.2020.118270.

Muhammad, M.T., Khan, K.M., Arshia, Khan, A., Arshad, F., Fatima, Bibi, Choudhary, M.I., Syed, N., Moin, S.T., (2017). Syntheses of 4,6dihydroxypyrimidinediones, their urease inhibition, in vitro, in silico, and kinetic studies. Bioorg. Chem. 75, 317-331. https://doi.org/10.1016/j.bioorg.2017.08.018.

Mulvaney, R.L., Bremner, J.M., (1981). Use of urease and nitrification inhibitors for control of urea transformations in soils, in: E.A. Paul, J.N. Ladd (Eds.), Soil Biochem. 5, 153-196. 
Putatunda, S., Chakraborty, A., (2014). $\mathrm{A} \mathrm{Cs}_{2} \mathrm{CO}_{3}$-mediated simple and selective method for the alkylation and acylation of 3,4-dihydropyrimidin-2(1H)thiones. Comptes Rendus Chimie. 17, 1057-1064. https://doi.org/10.1016/j.crci.2013.12.006.

Rego, Y.F., Marcelo, P., Queiroz, T., Brito, O., Priscila, G., Vagner, C., Queiroz, T., Fátima, A., Macedo F., (2018). A review on the development of urease inhibitors as antimicrobial agents against pathogenic bacteria. J Adv Res. 13, 69-100. https://doi.10.1016/j.jare.2018.05.003.

Shamim, S., Khan, K.M., Salar, U., Ali, F., Lodhi, M.A., Taha, M., Khan, F.A., Ashraf, S., Ul-Haq, Z., Ali, M., Perveen, S., (2018). 5-Acetyl-6-methyl-4aryl-3,4-dihydropyrimidin-2(1H)-ones: As potent urease inhibitors; synthesis, in vitro screening, and molecular modeling study. Bioorg. Chem. 76, 37-52. https://doi.org/10.1016/j.bioorg.2017.10.021.

Stingl, K., Altendorf, K., Bakker, E.P., (2002). Acid survival of Helicobacter pylori: how does urease activity trigger cytoplasmic $\mathrm{pH}$ homeostasis? Trends Microbiol.10, 70-74. https://10.1016/s0966-842x(01)02287-9.

Taha, M., Ismail, N.H., Imran, S., Wadood, A., Rahim, F., Riaz, M., (2015). Synthesis of potent urease inhibitors based on disulfide scaffold and their molecular docking studies. J. Bioorg. Med. Chem. 23, 7211-7218. https://doi.10.1016/j.bmc.2015.10.017.

Weatherburn, M., (1967). Phenol-hypochlorite reaction for determination of ammonia, Anal. Chem. 39, 971-974. https://doi.org/10.1021/ac60252a045.

Weber, M., Jones, M.J., Ulrich, J., (2008). Optimization of isolation and purification of the jack bean enzyme urease by extraction and subsequent crystallization. J. Food. Bioprod. Proc. 86, 43-52. https://doi.10.1016/j.fbp.2007.10.005. 


$$
\begin{aligned}
& \text { مثبطات اليورياز الفعالة: التصميم والتشييد والإرتباط الجزيئي وتقييم الخواص الحركية لهجين داي } \\
& \text { هيدروبيرميالين فيثاليميذ } \\
& \text { أحمد أبو الفتوح السيد مر اد'،*، مي أبو الفتوح السيد مر اد׳ }
\end{aligned}
$$

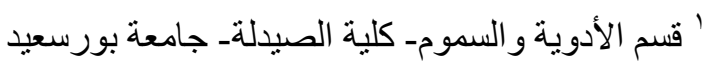



ahmed.mourad@yahoo.com البريد الإكتروني للباحث الرئيسي:

حظي تتبيط عمل إنزيم اليورياز باهتمام كبير للتغلب على العديد من أمراض الجهاز الجهاز الهضمي والكلى مثل

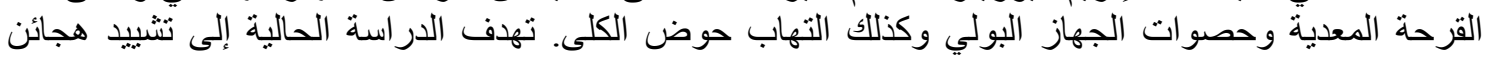

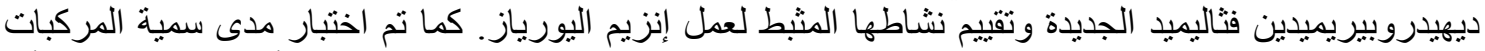

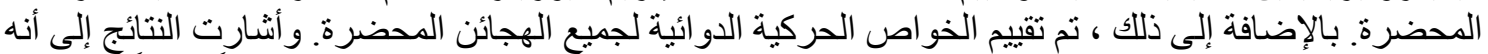





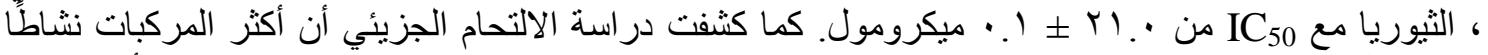

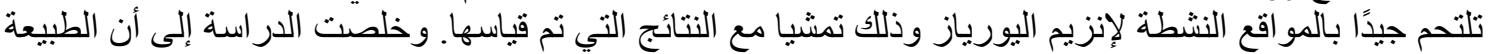

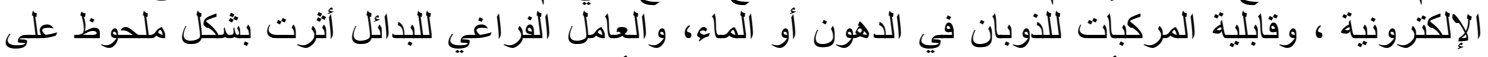

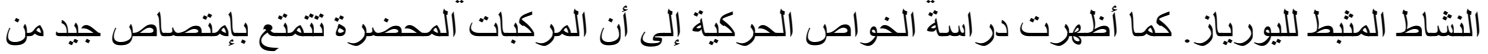

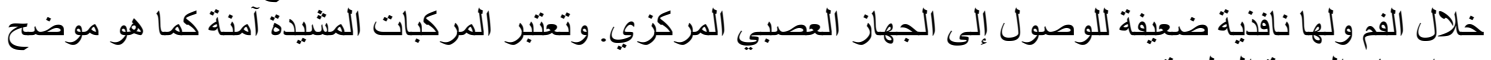
في اختبار السمية الخلوية.

الكلمات المفتاحية: مثبطات اليوريا ، ديهيدروبيريميدين ، فثناليميد ، السمية الخلوية ، القرحة المعدية ، التهاب حوض الكلي، جرثومة المعدة. 